\title{
PENGARUH STRATEGI PEMBELAJARAN RELATING, EXPERIENCING, APPLYING, COOPERATING, AND TRANSFERRING (REACT) TERHADAP KEMAMPUAN KOMUNIKASI MATEMATIS SISWA KELAS VII DI MTS ASH-SOHIBIYAH BANGUN PURBA
}

\author{
Lili Hardiyah Hafisani ${ }^{1}$, Annajmi², Arcat ${ }^{3}$ \\ $1,2,3$ Universitas Pasir Pengaraian \\ ilylili909@gmail.com
}

\begin{abstract}
This study aims to determine whether or not there is an effect of the Relating, Experiencing, Applying, Cooperating, and Transferring (REACT) learning strategy on the mathematical communication skills of grade VIl students at MTs Ash-Shohibiyah Bangun Purba. This type of research is a Quasi Experiment study with the Posttest Only Control Group Design design. This study's population were students of class VII MTs Ash-Shohibiyah Bangun Purba with a sample of class VII. 1 and class VII.2. Samples were obtained using random sampling techniques. The experimental class uses the REACT strategy, while the control class uses conventional learning. This research instrument is a question of a description of mathematical communication skills. Posttest data on mathematical communication skills obtained were analyzed data to test the hypothesis. The normality test results showed that data were normally distributed, and the homogeneity test results showed that the data had variants that were not homogeneous. Hypothesis testing used the t 'test because the data were normally distributed and not homogeneous. The results of the calculation concluded that there was an effect of the learning strategy of Relating, Experiencing, Applying, Cooperating, and Transferring (REACT) on the mathematical communication skills of grade VIl students at MTs Ash-Shohibiyah Bangun Purba.
\end{abstract}

Keywords: Relating, Experiencing, Applying, Cooperating, and Transferring (REACT), mathematical communication ability.

\begin{abstract}
ABSTRAK Penelitian ini bertujuan untuk mengetahui ada atau tidaknya pengaruh strategi pembelajaran Relating, Experiencing, Applying, Cooperating, and Transferring (REACT) terhadap kemampuan komunikasi matematis siswa kelas VII di MTs Ash-Shohibiyah Bangun Purba. Jenis penelitian ini adalah penelitian Quasi Eksperiment dengan desain the Posttest Only Control Group Design. Populasi pada penelitian ini adalah siswa kelas VII MTs AshShohibiyah Bangun Purba dengan sampel kelas VII.1 dan kelas VII.2. Sampel diperoleh menggunakan teknik random sampling. Kelas eksperimen menggunakan strategi REACT, sedangkan kelas kontrol menggunakan pembelajaran konvensional. Instrumen penelitian ini adalah soal uraian kemampuan komunikasi matematis. Data posttest kemampuan komunikasi matematis yang diperoleh dilakukan analisis data untuk menguji hipotesis. Hasil uji normalitas diperoleh data berdistribusi normal dan hasil uji homogenitas diperoleh data memiliki varian yang tidak homogen. Pengujian hipotesis menggunakan uji †' karena data berdistribusi normal dan tidak homogen, hasil perhitungan diperoleh kesimpulan bahwa ada pengaruh strategi pembelajaran Relating, Experiencing, Applying, Cooperating, and Transferring (REACT) terhadap kemampuan komunikasi matematis siswa kelas VII di MTs AshShohibiyah Bangun Purba.
\end{abstract}

Kata-kata Kunci : Relating, Experiencing, Applying, Cooperating, and Transferring (REACT), kemampuan komunikasi matematis. 


\section{PENDAHULUAN}

Siswa merupakan fokus utama dalam proses pembelajaran. Keberhasilan pencapaian tujuan pembelajaran banyak tergantung kepada kesiapan dan cara belajar yang dilakukan oleh siswa. Dalam pembelajaran siswa dituntut untuk dapat berperan aktif, kreatif, dan mandiri dalam menyelesaikan permasalahan dengan baik, salah satunya dalam pembelajaran matematika. Pentingnya penguasaan matematika terlihat pada Undang-Undang RI No. 20 Th. 2003 tentang Sisdiknas Pasal 37 ditegaskan bahwa mata pelajaran matematika merupakan salah satu mata pelajaran wajib bagi siswa pada jenjang pendidikan dasar dan menengah.

Permendikbud Nomor 58 Tahun 2014 menyatakan bahwa tujuan mata pelajaran matematika adalah agar peserta didik memiliki kemampuan memahami konsep matematika, memecahkan masalah, mengkomunikasikan gagasan dengan simbol, tabel, diagram, atau media lain untuk memperjelas keadaan atau masalah. Dari tujuan tersebut jelaslah bahwa kemampuan komunikasi matematis merupakan salah satu kemampuan dasar yang sangat penting untuk dimiliki peserta didik dalam kegiatan belajar mengajar.

Mengingat hal tersebut, kemampuan komunikasi adalah salah satu kemampuan dalam matematika yang mendasar yang harus dikuasai oleh siswa (Asnawati, 2017). Kemampuan komunikasi penting untuk dikembangkan karena kemampuan komunikasi dapat membantu siswa dalam memahami masalah-masalah matematika yang disajikan dan mengemukakan gagasan-gagasan penyelesaian dan persoalan tersebut, serta memberikan argumen atau ide yang diutarakannya (Sugandi \& Bernard, 2018). Proses komunikasi yang baik dalam pembelajaran matematika, apabila siswa mampu mengkontruksi pengetahuan yang diperoleh.

Kemampuan komunikasi matematis menurut Izzati (Sari dkk, 2018) merupakan kemampuan menggunakan bahasa matematis untuk mengekspresikan gagasan dan argumen secara tepat, singkat, dan logis. Ini berarti apabila peserta didik memiliki kemampuan komunikasi yang baik maka dapat menginterpretasikan dan mengekspresikan pemahaman konsep yang mereka pelajari, lebih lanjut peserta didik dapat menyelesaikan masalah dengan baik. Selain itu dapat diatrikan bahwa kemampuan komunikasi matematis merupakan kemampuan mengkomunikasikan gagasan dengan simbol-simbol, grafik, atau diagram untuk menjelaskan suatu keadaan atau masalah (Anggarini \& Septian, 2019). Secara umum, kemampuan komunikasi matematis dapat dibedakan menjadi dua, yaitu kemampuan komunikasi matematis lisan dan kemampuan komunikasi tertulis (Musna, 2018). Adapun kemampuan komunikasi matematis yang dimaksud dalam penelitian ini adalah kemampuan komunikasi matematis tertulis. Berdasarkan pendapat para ahli di atas kemampuan komunikasi matematis adalah kemampuan siswa dalam menyampaikan ide-ide matematis melalui argumen dalam bahasa matematika baik secara lisan maupun tulisan.

Berdasarkan hasil observasi di MTs As-Shohibiyah Bangun Purba menunjukkan bahwa penyebab rendahnya kemampuan komunikasi matematis siswa, yaitu pertama selama ini proses pembelajaran disampaikan secara informatif seperti (konsep, teorema, rumus, dan sebagainya), dan siswa diminta menulis kembali lalu menghafalnya tanpa melalui proses penemuan. Hal ini membuat siswa tidak melakukan proses berpikir, sehingga ide-ide matematis siswa yang merupakan kemampuan komunikasi matematis siswa tidak terlatih dalam proses pembelajaran. Kedua, dalam mengerjakan latihan-latihan soal, siswa cenderung mengikuti langkah- 
langkah dari contoh soal yang diberikan oleh gurunya. Hal ini membuat siswa bergantung pada guru dan langkah-langkah dari contoh soal yang diberikan, sehingga siswa menjadi tidak kreatif dan tidak mampu berpikir kritis dalam mengkomunikasikan ide-idenya untuk menemukan langkah-langkah baru ketika menyelesaikan suatu permasalahan. Ketiga, siswa lupa (keliru) menggunakan konsep, teorema, rumus dan sebagainya yang akan digunakan dalam menyelesaikan masalah. Hal ini disebabkan karena kecenderungan siswa yang hanya menghafal, bukan dengan memahami bagaimana mengkomunikasikan suatu konsep, teorema ataupun rumus itu diperoleh.

Menyikapi masalah tersebut, maka perlu dilakukan cara untuk meningkatkan kemampuan komunikasi matematis siswa. Salah satu cara untuk meningkatkan kemampuan komunikasi matematis, yaitu guru perlu menerapkan strategi pembelajaran yang dapat memacu keaktifan siswa, bekerjasama dengan siswa dalam tugas-tugas terstruktur dan saling berinteraksi satu sama lain secara aktif dan efektif serta dapat mengembangkan kemampuan komunikasi matematis siswa. Strategi pembelajaran yang bisa diterapkan adalah strategi pembelajaran Relating, Experiencing, Applying, Cooperating, and Transferring (REACT).

Terkait dengan strategi REACT, Center of Occupational Research and Depelopment (Sari dkk, 2018) menjabarkan lima komponen yang harus tampak yaitu Relating adalah mengaitkan konsep-konsep baru yang akan dipelajari dengan konsep yang telah dipelajari atau pengalaman kehidupan sehari-hari. Experiencing adalah melakukan explorasi, pencarian, dan penemuan konsep baru yang akan dipelajari. Appliying adalah mengaplikasikan konsep yang telah ditemukan. Cooperating adalah saling berbagi, saling merespon dan berkomunikasi antar siswa. Transferring adalah menggunakan pengetahuan yang dimiliki dalam konteks baru. Strategi ini mendorong siswa untuk berpikir dan menjelaskan penalaran mereka daripada sekedar mengingat fakta, membantu siswa untuk melihat hubungan Antara berbagai tema dan konsep (Crawford, 2001).

Komponen pembelajaran pada strategi REACT memberikan peluang peserta didik untuk meningkatkan kemampuan komunikasi matematis. Misalnya, saat proses mengaitkan atau relating, peserta didik diberikan pertanyaan mengenai materi yang akan dipelajari dengan pengetahuan yang telah dipelajari atau pengalaman kehidupan sehari-hari. Hal ini melatih peserta didik untuk mengkomunikasikan ide atau gagasannya. Pada proses mengalami atau experiencing, siswa dituntut untuk belajar melalui kegiatan explorasi, pencarian, dan menemukan konsep baru yang akan dipelajari. Hal ini akan membuat siswa melakukan proses berpikir, sehingga ideide matematis siswa yang merupakan kemampuan komunikasi matematis siswa akan terlatih dalam proses pembelajaran. Selanjutnya mengaplikasikan atau applying, peserta didik dituntut untuk dapat menerapkan konsep yang telah ditemukan untuk memecahkan masalah yang dihadapi. Hal ini akan membuat siswa menjadi kreatif dan mampu berpikir kritis dalam mengkomunikasikan ide-idenya guna menemukan langkah-langkah baru untuk menyelesaikan suatu permasalahan. Saat berdiskusi atau cooperating, peserta didik dibiasakan untuk saling berbagi, saling merespon, dan berkomunikasi dengan sesama temannya. Lalu saat proses mentransfer atau transferring, peserta didik dituntut memilki kemampuan untuk bisa menerapkan pengetahuan yang dimilikinya dalam konteks baru. Setelah melalui proses pada kelima komponen di atas siswa tidak lagi cendrung hanya menghafal, tetapi mampu memahami bagaimana mengkomunikasikan suatu konsep dan menerapkannya. Sehingga siswa tidak mudah lupa (keliru) ketika mengkomunikasikan ide-ide 
matematisnya dalam menyelesaikan masalah. Hal ini sejalan dengan arifin, dkk (2014) bahwa pembelajaran matematika harus dipelajari dalam konteks yang bermakna yang mengaitkannya dengan subjek lain dan pengalaman siswa.

\section{METODE PENELITIAN}

Penelitian ini merupakan penelitian eksperimen semu (Quasi Eksperiment) dengan desain "the posttes only control group design". Desain ini dinyatakan dalam Tabel 1.

Tabel 1. Desain Penelitian The Posttes Only Control Group Design

Keterangan:

\begin{tabular}{|l|l|l|}
\hline \multicolumn{1}{|c|}{ Kelas } & Perlakuan & Posttest \\
\hline Eksperimen & $\mathrm{X}$ & $\mathrm{O}$ \\
\hline Kontrol & - & $\mathrm{O}$ \\
Sugiyono (2017)
\end{tabular}

$\mathrm{X} \quad=$ Pembelajaran dengan menggunakan pembelajaran strategi REACT

- $\quad=$ Pembelajaran dengan menggunakan pembelajaran konvesional

$0 \quad=$ Tes kemampuan komunikasi matematis.

Penelitian ini dilaksanakan di kelas VII MTs Ash-Shohibiyah Bangun Purba pada semester ganjil tahun ajaran 2019/ 2020 pada materi pokok persamaan dan pertidaksamaan linear satu variabel. Populasi dalam penelitian ini adalah seluruh siswa kelas VII MTs Ash-Shohibiyah Bangun Purba. Teknik pengambilan sampelnya menggunakan teknik random sampling, untuk menentukan kelas eksperimen dan kelas kontrol dilakukan secara random yaitu dengan cara undian. Dalam penelitian ini, terpilihlah kelas VII.1 sebagai kelas eksperimen dan kelas VII.2 sebagai kelas kontrol. Teknik pengumpulan data dalam penelitian ini dilakukan dengan mengunakan teknik tes dan instrumen yang digunakan berupa soal uraian yang disusun berdasarkan indikator kemampuan komunikasi matematis. Analisis data menggunakan uji prasyarat, yaitu uji normalitas menggunakan uji Lilifors dan uji homogenitas menggunakan uji Fisher. Hipotesis data menggunakan uji t'.

\section{HASIL DAN PEMBAHASAN}

Hasil analisis data, secara deskriptif data posttest kemampuan komunikasi matematis siswa kelas VII MTs Ash-Shohibiyah Bangun dapat dilihat pada Tabel 2.

Tabel 2. Hasil Posttest Kemampuan Komunikasi Matematis

\begin{tabular}{|l|c|l|l|c|c|}
\hline Kelas & $\mathbf{N}$ & $\boldsymbol{X}_{\text {maks }}$ & $\boldsymbol{X}_{\min }$ & $\boldsymbol{S}^{2}$ & $\bar{X}$ \\
\hline Eksp & 29 & 100 & 44,44 & 12,70 & 83,91 \\
\hline Kont & 30 & 100 & 0 & 23,82 & 65,93 \\
\hline
\end{tabular}

Berdasarkan Tabel 2 terlihat rata-rata nilai posttest kemampuan komunikasi matematis siswa pada kelas eksperimen lebih tinggi dibandingkan dengan rata-rata nilai posttest kemampuan komunikasi matematis siswa kelas kontrol. Jika dilihat dari 
nilai minimum kelas eksperimen lebih tinggi dari pada kelas kontrol. Adapun perolehan skor siswa berdasarkan tiap indikator kemampuan komunikasi matematis dapat dilihat pada Tabel 3 berikut:

Tabel 3. Hasil Deskripsi Data Kemampuan Komunikasi Matematis Setiap Indikator

\begin{tabular}{|c|c|c|c|}
\hline No & Indikator & Kelas & Rata-rata \\
\hline \multirow{2}{*}{1} & \multirow{2}{*}{$\begin{array}{l}\text { Kemampuan siswa dalam menyimpulkan hasil } \\
\text { dalam bentuk tulisan }\end{array}$} & Eksperimen & 2,97 \\
\hline & & Kontrol & 2,40 \\
\hline & \multirow{2}{*}{$\begin{array}{l}\text { Kemampuan siswa dalam menjelaskan ide, situasi, } \\
\text { relasi, matematis secara tulisan dengan benda } \\
\text { nyata, gambar, grafik, dan aljabar }\end{array}$} & Eksperimen & 2,28 \\
\hline & & Kontrol & 1,87 \\
\hline \multirow{2}{*}{3} & \multirow{2}{*}{$\begin{array}{l}\text { Kemampuan dalam menyatakan suatu situasi, } \\
\text { gambar, diagram atau benda nyata kedalam } \\
\text { bahasa, simbol, ide, atau model matematika }\end{array}$} & Eksperimen & 2,31 \\
\hline & & Kontrol & 1,67 \\
\hline
\end{tabular}

Berdasarkan Tabel 3 menggambarkan rata-rata kemampuan komunikasi matematis siswa dilihat untuk setiap indikator pada soal posttest. Terlihat bahwa setiap indikator terdiri dari satu soal yaitu indikator 1 untuk soal nomor 1, indikator 2 untuk soal nomor 2 dan indikator 3 untuk soal nomor 3 , diketahui rata-rata skor pada kelas eksperimen lebih tinggi dari pada kelas kontrol. Hal ini memperlihatkan kemampuan komunikasi matematis kelas eksperimen lebih baik dibandingkan kelas kontrol yang ditinjau dari setiap indikator.

Sebelum data hasil tes kemampuan komunikasi matematis siswa pada kedua kelas sampel dilakukan pengujian hipotesis, terlebih dahulu dilakukan uji prasyarat yaitu uji normalitas dan uji homogenitas homogenitas kemudian dilanjutkan dengan uji hipotesis. Hasil uji normalitas posttest dapat dilihat pada Tabel 4.

Tabel 4. Hasil Uji Normalitas Data Posttest

\begin{tabular}{|l|l|l|l|}
\hline Kelas & \multicolumn{1}{|c|}{ Lhitung } & L tabel & \multicolumn{1}{c|}{ Kriteria } \\
\hline Eksperimen & 0,146 & 0,173 & $\begin{array}{l}\text { Berdistribusi } \\
\text { normal }\end{array}$ \\
\hline Kontrol & 0,1008 & 0,173 & $\begin{array}{l}\text { Berdistribusi } \\
\text { normal }\end{array}$ \\
\hline
\end{tabular}

Berdasarkan Tabel 4 terlihat bahwa kesimpulan untuk kelas eksperimen yaitu Lhitung < $L_{\text {tabel }}$ dan kelas kontrol yaitu Lnitung $<L_{\text {tabel }}$ yang berarti terima $\mathrm{H}_{0}$. Taraf signifikan yang digunakan dalam penelitian ini adalah $a=0,05$. Hal ini menunjukan bahwa data posttest kelas eksperimen dan kontrol berdistribusi normal. Karena data berdistribusi normal, dilanjutkan dengan uji homogenitas varian menggunakan uji Fisher diperoleh untuk kelas eksperimen dan kontrol yaitu, $F_{\text {hitung }}=2,4159$ dan $F_{\text {tabel }}=1,8752$ dengan taraf signifikan yang digunakan dalam penelitian ini adalah $a=0,05$. Karena $F_{\text {hitung }}>F_{\text {tabel }}$ maka tolak $\mathrm{H}_{0}$. Hal ini menunjukkan bahwa data posttest kelas eksperimen dan kelas kontrol memiliki varian tidak homogen.

Hasil pengujian hipotesis mengunakan $u j i \quad t^{\prime}$ diperoleh nilai $t^{\prime}{ }_{\text {hitung }}=$ $3,4191,-\frac{w_{1} t_{1}+w_{2} t_{2}}{w_{1}+w_{2}}=-2,0459$, dan $\frac{w_{1} t_{1}+w_{2} t_{2}}{w_{1}+w_{2}}=2,0459$ dengan taraf signifikan yang 
digunakan adalah $\alpha=0,05$. Karena $-2,0459<3,4601>2,0459$ maka tolak Ho. Hal ini berarti ada pengaruh strategi pembelajaran REACT (Relating, Experiencing, Applying, Cooperating, and Transferring) terhadap siswa kelas VII di MTs AshShohibiyah Bangun Purba.

Adapun bentuk peranan-peranan strategi pembelajaran REACT terhadap kemampuan komunikasi matematis siswa terlihat pada proses pembelajarannya. Komponen pertama adalah relating atau mengaitkan, siswa mengamati sebuah masalah yang terdapat di dalam sebuah dialog. Siswa diminta untuk mengingat kembali materi sebelumnya untuk memahami bagaimana cara mengkomunikasikan suatu situasi ke dalam model matematika. Kemudian siswa diminta menuliskan unsurunsur dari model matematika yang telah disajikan, mana variabel, koefisien, dan konstanta sekaligus mendefenisikan unsur-unsur tersebut.

Komponen kedua adalah experiencing atau mengalami, siswa diminta mengelompokkan kalimat-kalimat pada dialog sebelumnya menjadi tiga kalimat, yaitu kalimat tidak dapat dinilai kebenarannya, kalimat yang bernilai benar saja, dan kalimat yang bernilai salah saja. Sehingga siswa mampu memahami defenisi kalimat terbuka dan tertutup. Kemudian siswa dibimbing untuk menemukan konsep persamaan linear satu variabel dengan mengikuti langkah-langkah pada LAS. Siswa diminta mengidentifikasi enam kalimat yang telah disajikan dengan menjawab beberapa pertanyan dan menuliskannya pada LAS. Setelah mengikuti beberapaa langkah akhirnya siswa sampai pada kesimpulan, di sini siswa diminta menuliskan kesimpulan dari pengertian persamaan linear satu variabel. Setelah menemukan konsep siswa diminta untuk menyelesaikan masalah yang terdapat pada dialog sebelumnya. Siswa diminta untuk mengubah sebuah kalimat terbuka yang dituliskan ke dalam model matematika hingga menemukan himpunan penyelesaiannya dengan mengikuti langkah-langkah yang disajikan. Langkah pertama siswa diminta mengubah kalimat tersebut ke dalam model matematika. Kemudian di LAS siswa dituntun untuk mengganti variabel dengan angka-angka dari bilangan asli untuk dioperasikan. Mengganti variabel mulai dari angka 1, jika hasil operasinya benar maka kata salah dicoret dan begitulah sebaliknya sampai menemukan operasi yang benar. Tujuannya untuk melatih pemahaman siswa sebelum mengerjakan latihan.

Komponen ketiga applying siswa diminta untuk mengerjakan latihan secara diskusi. Tujuannya agar siswa mampu menerapkan konsep yang sudah ditemukan sebelumnya untuk menyelesaikan masalah yang disajikan. Siswa diminta untuk menuliskan mana yang merupakan kalimat tertutup dan terbuka, jika tertutup tentukan nilai kebenarannya. Kemudian dari kalimat terbuka yang sudah dituliskan siswa diminta mengubahnya ke dalam model matematika. Nah, dari model matematika tersebut siswa diminta mengubahnya menjadi kalimat tertutup yang bernilai benar dengan menggunakan konsep pada pengerjaan soal sebelumnya. Setelah selesai perwakilan dari kelompok untuk menuliskan dan menjelaskan hasil diskusinya kedepan kelas. Pada komponen keempat transferring, siswa mampu menyelesaikan latihan yang diberikan sekaligus menjelaskan kekelompok lain. Dari keseluruhan komponen dalam strategi pembelajaran REACT dapat membantu siswa 
dalam melatih kemampuan komunikasi matematis mereka, sehingga kemampuan komunikasi matematis siswa semakin berkembang. Seperti yang diungkapkan oleh Pratama \& William (2018) bahwa penggunaan strategi REACT dapat memberikan kebermaknaan yang lebih bagi siswa dalam melakukan kegiatan pembelajaran.

Berbeda dengan penerapan pada pembelajaran konvensional siswa tidak duduk berdasarkan kelompok permanen yang sudah ditetapkan oleh guru. Siswa belajar secara individu, kelompok digunakan ketika guru memberikan tugas kelompok saja. Setelah membuka pelajaran, guru langsung mengawali pembelajaran dengan menjelaskan materi yang akan diajarkan. Jika ada yang tidak paham, siswa dipersilahkan untuk bertanya. Kemudian memberikan contoh soal dan menjelaskannya kepada siswa. Selanjutnya siswa diberikan soal latihan yang dikerjakan secara individu. Guru mengoreksi dan menilai hasil yang mereka kerjakan. Sebelum menutup pembelajaran guru menyimpulkan materi pelajaran pada hari itu.

Pembelajaran konvensional seperti yang diungkapkan dalam penelitian Nasution (2019) dimana siswa hanya menerima pengetahuan dari guru dan pembelajaran tidak dikaitkan dengan kehidupan sehari-hari siswa, siswa hanya menghafal apa yang disampaikan oleh guru. Pembelajaran konvensional tidak membuat siswa menerima pengetahuan lebih banyak karena langsung diberikan oleh guru. Pembelajaran hanya berorientasi pada menjelaskan materi pelajaran, menjelaskan langkah-langkah dalam menghitung di papan tulis dan memberikan contoh-contoh soal kemudian siswa diminta untuk mengerjakan soal. Seperti yang diungkapkan oleh Ruseffendi (Puandi, 2016) mendefenisikan pembelajaran konvensional adalah pembelajaran dimana guru mendominasi kelas, siswa pasif dan hanya menerima.

Pembelajaran konvensional biasanya diawali oleh guru memberikan informasi, kemudian menerangkan suatu konsep, siswa bertanya, guru memeriksa apakah siswa sudah mengerti atau belum, memberikan contoh soal aplikasi konsep, selanjutnya memberi siswa soal yang mirip dengan contoh soal. Selain itu pada kelas konvensional siswa kurang diberikan kesempatan untuk mengkonstruksi sendiri dalam menyelesaikan masalah. Hal ini membuat matematika hanya dipandang berupa sekumpulan rumus dan aturan yang harus dihafal serta diingat oleh siswa untuk memperoleh jawaban dari pertanyaan. Hal tersebut berbeda dengan kelas eksperimen yang dituntut untuk lebih mandiri, mengkonstruksi sendiri. Seperti yang diungkapkan oleh Nuriah (2019) bahwa pembelajaran matematika bukan hanya transfer of knowledge tetapi perlu peran aktif siswa sebagai subjek dalam belajar.

Kelas konvensional pada umumnya pembelajaran berpusat pada guru sehingga guru lebih banyak berperan dibandingkan siswa itu sendiri. Siswa tidak diberikesempatan untuk menemukan informasi baru maupun konsep dalam matematika. Suasana yang monoton juga dapat mengakibatkan siswa mudah bosan. Akibatnya hasil posttest kemampuan komunikasi matematis siswa kelas konvensional lebih rendah dibanding kelas eskperimen dengan strategi REACT. Sejalan dengan penelitian Herlina, dkk (2012) bahwa kemampuan komunikasi matematis siswa yang memperoleh pembelajaran dengan strategi REACT secara signifikan lebih baik daripada siswa yang memperoleh pembelajaran konvensional. 
Berdasarkan keterangan di atas dan hasil analisis uji hipotesis maka dapat disimpulkan bahwa ada pengaruh strategi pembelajaran Relating, Experiencing, Applying, Cooperating, and Transferring (REACT) terhadap kemampuan komunikasi matematis siswa kelas VII di MTs Ash-Shohibiyah Bangun Purba tahun ajaran $2019 / 2020$. Artinya ada perbedaan rata-rata kemampuan komunikasi matematis siswa menggunakan strategi REACT dengan rata-rata kemampuan komunikasi matematis siswa menggunakan pembelajaran konvensional.

\section{KESIMPULAN DAN SARAN}

Berdasarkan hasil penelitian mengenai pengaruh strategi pembelajaran Relating, Experiencing, Applying, Cooperating, and Transferring (REACT) terhadap kemampuan komunikasi matematis siswa kelas VII di MTs Ash-Shohibiyah Bangun Purba maka diperoleh kesimpulan bahwa: ada pengaruh strategi pembelajaran Relating, Experiencing, Applying, Cooperating, and Transferring (REACT) terhadap kemampuan komunikasi matematis siswa kelas VII di MTs Ash-Shohibiyah Bangun Purba dengan rata-rata kelas eksperimen 83,91 lebih besar dari rata-rata kelas kontrol $65,93$.

Berdasarkan kesimpulan yang telah dikemukakan, peneliti ingin mengajukan beberapa saran yang berhubungan dengan pelaksanaan strategi pembelajaran REACT dalam pembelajaran matematika, yaitu:

1. Strategi pembelajaran REACT dapat dijadikan salah satu alternatif pembelajaran pada mata pelajaran matematika yang bisa diterapkan oleh guru pada jenjang pendidikan sekolah menengah pertama.

2. Peneliti lain dapat menerapkan strategi pembelajaran REACT dikombinasikan dengan variabel-variabel lain dan untuk meningkatkan variabel lain.

3. Dalam proses pembelajaran, guru hendaknya dapat mengatur/mengkondisikan antara waktu dan jumlah siswa dalam kelas sebaik mungkin sehingga rencana pelaksanaan pembelajaran dapat terlaksana dengan baik.

Sekolah maupun guru harus mengetahui pentingnya kemampuan komunikasi matematis siswa, karena ketika kemampuan komunikasi matematis siswa baik akan berpengaruh terhadap hasil belajar siswa.

\section{DAFTAR PUSTAKA}

Anggraini, A, \& Septian, A., (2019). Peningkatan Kemampuan Komunikasi Matematis dan Kebiasaan Berpikir Siswa Melalui Model Pembelajaran IMPROVE. IndoMath: Indonesia Mathematics Education, 2(2), 105-116.

Arifin, A. T., dkk. (2014). Keefektifan Strategi Pembelajaran REACT pada Kemampuan Siswa Kelas VII Aspek Komunikasi Matematis. Kreano: Jurnal Matematika Kreatif-Inovatif, 5(1), 91-98.

Asnawati, S. (2017). Peningkatan Kemampuan Komunikasi Matematis Siswa SMP dengan Pembelajaran Kooperatif Tipe Teams Gamestournaments. Euclid, 3(2). 
Crawford, L. M. (2001). Teaching Contextually: Research, Rationale, and Techniques for Improving Student Motivation and Achievement in Mathematics and Science.Texax: CCI Publishing, INC.

Depdiknas RI. (2003). Undang-Undang Nomor 20 Tahun 2003. Jakarta: Depdiknas

Herlina, S. dkk. (2012). Efektivitas Strategi REACT Dalam Upaya Peningkatan Kemampuan Komunikasi Matematis Siswa Sekolah Menengah Pertama. Jurnal Pengajaran MIPA, 17(1), 1-7.

Musna, R. R. (2018). Meningkatkan Kemampuan Komunikasi Matematis Melalui Strategi Pembelajaran REACT pada Siswa MTs/SMP. (Skripsi, Universitas Islam Negeri Ar-Raniry).

Nasution, H. M. (2019). Pengaruh Strategi Pembelajaran REACT (Relating, Experiencing, Appliying, Cooperating, and Transferring) Terhadap Kemampuan Komunikasi Matematis Siswa Kelas VII Mts As-Sohibiyah Bangun Purba. (Skripsi, Universitas Pasir Pengaraian) Tidak diterbitkan.

Nuriah, S. (2019). Pengaruh Strategi Relating, Experiencing, Applying, Cooperating, and Transferring (REACT) Terhadap Kemampuan Komunikasi Matematis Siswa MI: Penelitian Kuasi Eksperimen pada Siswa Kelas V MI Terpadu Ar-Rifai Kabupaten Bandung (Docroral Dissertation, UIN Sunan Gunung Djati Bandung).

Permendikbud Nomor 58. (2014). Kurikulum 2013 Sekolah Menengah Pertama/Madrasah Tsanawiyah. Jakarta: Menteri Pendidikan dan Kebudayaan RI.

Pratama, Y. A., \& William, N. (2018). Efektivitas Pembelajaran REACT Terhadap Kemampuan Komunikasi Matematis Siswa. Jurnal Silogisme: Kajian IImu Matematika dan Pembelajarannya, 3(3), 94-104.

Puandi, E, F, W,. (2016). Meningkatkan Kemampuan Pemecahan Masalah Matematis Mahasiswa PTIK melalui pembelajaran Berbasis Masalah. Jurnal Matematika IImiah STKIP Muhammadiyah Kuningan, 2(2), 212-23.

Sari, N. R. dkk. (2018). Pengaruh Strategi Relating Experiencing Apllying Cooperating Transferring Terhadap Kemampuan Komunikasi Matematis Siswa. Jurnal Pendidikan Matematika Unila, 6(3), 210-220.

Sugandi, A. I., \& Bernard, M. (2018). Penerapan Pendekatan Kontekstual Terhadap Kemampuan Pemahaman dan Komunikasi Matematis Siswa SMP. Jurnal Analisa, 4(1), 16-23.

Sugiyono. (2017). Metode Penelitian Kuantitatif, Kualitatif, dan R \& G. Bandung: ALFABETA. 